a Research Institute where the fundamental problems relating to land use in the widest aspects can be investigated. They ask for reform in education to bring it into closer association with everyday life. And they wish for the addition of economists and sociologists as advisers on the staff of the Native Affairs Department.

The Council sees clearly that the time has passed when all Natives could have their own bits of land. To say nothing of those who live outside, there are now large numbers of landless people in the Reserves. The redundant Africans must be drafted to, and trained for, industry whether in the Reserves or outside. Both the Council and the Native Affairs Commission strongly condemn the present system of migratory labour: it is morally, socially, and economically wrong, say the Council. 'The whole substance of rural life is being undermined by interference with family life due to the absence of large numbers of the males at industrial centres, and the consequent drift of their families to undesirable surroundings in the towns', say the Commission. 'This absence of family discipline, with all its consequences, is an evil that presents one of the most serious problems which the Government has to face, and in all future developments earnest attention should be given to the setting aside of areas where permanent homes may be provided for industrialized Natives, and their families, within easy reach of their work.' 'This implies the building of Native townships, as, indeed, is being done in many places. Territorial segregation (or separation) is a thing of the past (if it ever existed or could have existed); residential segregation has come to stay.

\title{
Research in South Africa
}

THE South African Council for Educational, Sociological, and Humanistic Research has set aside funds not to exceed $f_{12}$,000 for financing two extensive surveys in sample areas of African life, one urban and one rural. The urban area to be investigated is the Atteridgeville Location, Pretoria, a Native township of about 1,350 houses built by white labour; and the data to be collected comprise the composition and origin of the population; social organization; economic conditions; social welfare; religion; housing and other facilities; crime and delinquency; health and health services; inter-racial attitudes; nutrition; and the educational system. Four experts (economist, sociologist, educationalist, doctor) on a full- or part-time basis, and four non-European field workers with clerical assistants, are to be engaged on this research for about a year; and it is suggested that assistance be obtained from the Universities of Witwaterstand and Pretoria and other agencies. For the rural survey the Victoria East district of the Ciskei has been chosen; it presents one of the most difficult problems in all the Union. The area and its physical conditions; soil and crops; the population; economic conditions; health and nutrition; social organization and education; all these are to be studied especially in view of the rehabilitation plans of the Native Affairs Department. The same number of experts and non-European field-workers are to be employed as for the urban survey-a sociologist, an economist, a soil expert, an expert of livestock and crops; and assistance is expected from Rhodes University College, Grahamstown; Fort Hare; and Fort Cox Agricultural College.

Assisted by a grant from the Rockefeller Foundation, the South African Institute of International Affairs appointed a full-time Research Secretary in June I947 and embarked upon the investigation of three subjects: (a) Land tenure in Africa south of the Sahara; (b) The High Commission Territories; and (c) Transport and Communications in southern Africa. Miss Helen Scroggie is engaged upon the first of these projects; she will estimate the effect of different types of European control and native policy upon different types of indigenous land system. Sir Charles Dundas, a former Governor of Uganda, is preparing one section of a book on the historical, political, and constitutional aspects of the High Commission Territories; and Dr. Hugh Ashton will deal with their ethnography. A third section, on the 
economics, is to be arranged. It has not yet been possible to proceed with the study of transport and communications.

\section{The need for training of Officials in South Africa}

IN the course of a Presidential Address to section $E$ of the South Aftican Association for the Advancement of Science in July 1939, Professor I. Schapera made this remark: "It is somewhat ironic that in a country where at least six Universities and University Colleges have Departments of Bantu Studies, none of these Departments is actively engaged in preparing candidates for acceptance by the Native Affairs Department, although several young South Africans who have made a special study of Native life and languages have found their qualifications a decided asset for admission into the Rhodesian and British Colonial Services.' In 1947 the position remains as it was in 1939. 'The Union has had, since I925, an Ethnological section of the Native Affairs Department and its slender staff, headed by Dr. Van Warmelo, has done good work. The Native Affairs Department numbers among its officers many men who, as the writer of this Note can testify from recent personal experience, have wide and accurate knowledge of the peoples among whom they have laboured, some for thirty or forty years, and speak the languages fluently. A large proportion of them are sons of missionaries, born and bred among the Native people. But the most experienced of them are the first to lament that their knowledge is extremely limited, being confined to the tribes of which they have personal experience. They know little or nothing of the peoples outside the Union and of the great developments that are taking place in the British, French, and Belgian territories. One highly placed officer went on a tour of inspection to Nigeria; and some British officials have toured native areas of the Union. It would be to the mutual advantage of all the territories if interchange of this sort were greatly extended, for the Union has something to teach and something to learn. The Native Affairs Commission have proposed this. And it would be, in our opinion, highly profitable to the Union if the present hiatus between the Native Affairs Department and the University Schools of Bantu Studies were closed and if a training on the lines of that given to British, French, and Belgian officers were made available to, and required of, South Africans in their own institutions. At present there is no organized training in Bantu studies whether before or after appointment to responsible posts in the Native Affairs Department.

\section{Bursaries for African Medical Training in S. Rhodesia}

THE Government has announced that provisions have been made for a bursary to allow one African student a year to take his degree at a Union University. These bursaries are to carry a value of $f_{1} 100$ for the first year at Fort Hare and then $f_{250}$ per annum for the following five years at the University. It is the intention of Government, if suitable Africans are available, to allocate a bursary each year so that after six years there will be possibly six Africans receiving bursaries to assist medical training. The interest accruing from the Admiral Tait Memorial Fund is to be used to assist these students to buy books, \&c.

\section{Les Etudes Sociologiques en A.E.F.}

UN arrêté du Gouverneur Général crée à Brazzaville une 'Commission d'Études Sociologiques ' composée des chefs des services dont l'activité est plus particulièrement intéressée par les questions sociales. La commission est chargée de:

I. Coordiner l'organisation des enquêtes sociologiques sur le territoire de l'A.É.F.

2. Faire rassembler tous les renseignements d'ordre sociologique obtenus par les divers services du Gouvernement Général: 